\title{
Is the Education - Entrepreneurship Link Uncoupling?
}

\author{
Elisabeth M Struckell \\ University of North Texas
}

Researchers have established a strong link between education and both entrepreneurial intent and entrepreneurial performance. Yet, for some time, and certainly since the 2008 financial crisis, entrepreneurial activity rates have been declining while education levels are at an all-time high and access to entrepreneurship education is ubiquitous as supported by an independent study. Three converging factors are discussed as catalysts to this unfolding paradox-the recession, the growth in size and power of large corporations, and a generational shift. Implications to public policy and higher education are discussed.

\section{INTRODUCTION}

"The spirit of entrepreneurship was built into the country's DNA" (Greenspan \& Wooldridge, 2018, 8). Small business and entrepreneurial startups represent a critical component of U.S. domestic growth. Small business growth has been the backbone of the economy and part of the American dream (Carland \& Carland, 2015; Harrison, 2013; Kuratko, 2005). Entrepreneurial firms are the generators of new ideas and technology, and provide an avenue for economic pursuit (Kuratko, 2005). Small businesses have historically contributed 50\% of GDP (SBA.com, 2017). Recently, the Chairman of the House Small Business Committee was quoted, "when small businesses are strong, America is strong." (The White House, 2018). New businesses (under one year in operation) have been responsible for nearly all net new jobs created annually (Long, 2016). In fact, young company annual job creation has been greater than the cumulative number of new jobs created by all other company groupings (by age of company). Historically, turbulent environments characterized by change and unpredictability, like the one we face today, have presented fertile ground for entrepreneurs (Hmieleski \& Baron, 2016).

Given their importance to the economy and considering the environmental dynamism that should support new business growth, it is troubling to learn that new business and entrepreneurial startups have been in decline - more so in the decade following the financial crisis. According the Kauffman Foundation, the number of startups per working age American is at its lowest point since the recession (Fairlie, Morelix, Reedy \& Russell, 2015). The economy is recovering, but the rate of small business creation is not. In 2008, for the first time in U.S. history, the exit rate of firms exceeded firm entry rate and the gap between entry and exit has continued to widen. While small businesses historically represented the largest share of U.S. firm employment and growth, established companies now represent the majority (BLS.com, 2017); "the number of new companies being created has reached a modern low" (Greenspan \& Wooldridge, 2018, p.4). 
Researchers have established a strong link between education and entrepreneurial intent, action and success (Martin, McNally, \& Kay, 2013). The steady decline in new business formation over the past decade is confounded by education levels that are at an all-time high. More Americans are earning high school diplomas and bachelor's degrees than ever before, and entrepreneurship education is pervasive in educational institutions of all kinds.

This article surfaces an unfolding paradox - education has been linked to entrepreneurial intention and activity. Educational levels are at an all-time high. Further, entrepreneurial education access is ubiquitous in secondary educational institutions. Yet, startup activity is at historically low levels. Evidence of each claim is provided, and potential causes and associated implications are discussed. The study hopes to create a sense of urgency for researchers, educators and policy makers to coalesce around this "national emergency" (Buchanan, 2017).

\section{LITERATURE REVIEW}

\section{The Education Entrepreneurship Link}

Education level has been found to be positively related to individual productivity in general and the human capital theory supports positive returns on education investments for both entrepreneurs and traditional employees (Block, Hoogerheide, \& Thurik, 2011). Quite simply, higher levels of education lead to higher earnings (Marvel, Davis, \& Sproul, 2016). In a review of 104 studies of the human capital and entrepreneurship relationship, education level was the second most frequently used construct (behind work experience and ahead of entrepreneurial experience) and the link between human capital attributes and entrepreneurial success was strongly supported (Marvel, Davis, \& Sproul, 2016; Unger, Rauch, Frese, $\&$ Rosenbusch, 2011). The authors of one study characterize human capital as "vital to discovering and creating entrepreneurial opportunity" (Marvel et al., 2016, p. 599).

The literature supports a positive relationship between higher education levels and both entrepreneurial choice and performance (Block et al., 2011; Eesley \& Roberts, 2012; Lofstrom, Bates, \& Parker, 2014; Maria, Praag, \& Stel, 2011). A wide array of studies support the link between higher education and the likelihood to choose self-employment or to exploit entrepreneurial opportunity (Shane, 2003). While earlier studies showed a weak relationship between education and entrepreneurial choice, Block et al. (2011) discovered that using an instrumental variable analysis approach eliminated bias and yielded a positive and significant result. In a study including more than 10,000 self-employed and traditional employees from the U.S. and Europe, the effect of education on the decision to become selfemployed was found to be significant, strong and positively related - the higher the level of education, the stronger the likelihood that the individual will start a business (Block et al., 2011). In another study, authors focused on the effects of educational background and personal wealth on small business entry and found that advanced education facilitates entrepreneurial entry (Lofstrom et al., 2014).

One of the strongest drivers of entrepreneurial performance, regardless of the chosen measure, is human capital - developed through education investment (Maria et al., 2011). Research indicates that education level is not only relevant to the individual entrepreneur but that the education level of the stakeholders and community are all drivers of entrepreneurial success. Founder education has been shown to consistently improve the performance of new ventures (Shane, 2003). In an empirical review and metaanalysis of the education link to entrepreneurship selection and performance in developed countries, authors found support for a significant positive relationship between education and performance including earnings, growth and survival, especially strong in the United States (Van Der Sluis, Van Praag, \& Vijverberg, 2008). The authors were able to quantify a marginal year of education to provide a $6.1 \%$ return on entrepreneurship performance.

The linkage between education and entrepreneurship intent, career choice and performance is supported in literature as discussed. Higher levels of education promote entrepreneurship, which in turn drives economic growth (Thurik, 2008). 


\section{Education Attainment in the U.S. is at Historic Highs}

According to statistics tracked and reported annually by the Department of Education and the U.S. Census Bureau, the percentage of the population attaining both high school and college degrees is at an all-time high (Rampell, 2013; Ryan \& Bauman, 2016; Wilson, 2017). High school attainment, first reported at approximately $50 \%$ in the $1940 \mathrm{~s}$, has risen steadily to $92 \%$ (NCES, 2018), superseding a stated goal of President Obama to reach $90 \%$ by 2020 (NCES, 2018). The increase in high school educational attainment has been positively influenced by the No Child Left Behind Act (Ryan \& Bauman, 2016). Likewise, the attainment of an associate's or higher degree, among 25-29-year-olds, reached a record 46\% in 2017 (NCES, 2018). Attainment of a bachelor's degree has increased remarkably from less than 5\% in 1940 (Wilson, 2017) to 36\% in 2017 (NCES, 2018). The initial rise in college enrollment was the result of the GI Bill, following WWII. A second surge came from female enrollment, following the introduction of the Title IX educational amendments in the 1970s (Rampell, 2013). More recently, the rise in the number of higher education degrees, including associate, bachelor's, masters and doctorates, is the result of educational institutions aggressively focusing on both growing enrollments and graduation percentages (Rampell, 2013).

\section{Ubiquitous Presence of Entrepreneurship Education - Empirical Contribution}

Not only is education in general at an all-time high, access to entrepreneurship education has grown exponentially across campuses. It has been noted that the first entrepreneurship course on record was offered by the Harvard Business School in 1947 and the first MBA and undergraduate degrees in entrepreneurship were offered by the University of Southern California in the early 1970s, coincident with exponential growth in the number of entrepreneurial firms (Kuratko, 2005). The National Survey of Entrepreneurship Education is the oldest and most comprehensive survey on small business management and entrepreneurship education (CFEE, 2014). The report has been published by George Washington University Center for Entrepreneurial Excellence since 1979. In the most recent publication of results, 208 completed surveys from four-year institutions reflect a steady increase in the prevalence and types of entrepreneurship programs offered (CFEE, 2014). While literature reflecting the expansion of types of entrepreneurship offerings as well as significant growth in the availability of higher education entrepreneurship educational programs is compelling (Kuratko, 2005; Nabi, Liñán, Fayolle, Krueger, \& Walmsley, 2016), I was unable to find an adequate measure of the prevalence or breadth of entrepreneurship education in the U.S. As such, I contribute findings from an empirical study of the level of curriculum offered at the top 250 four-year public universities, top 250 four- year private universities, and top 250 community colleges.

\section{Sample and Methodology}

The total sample size is 750 institutions of higher learning $(n=750)$. The balanced sample includes the top 250 colleges in each category across public, private, and community levels based on the ranking criteria of US News \& World Report (public) and StateUniversity.com (private and community). Two sources were used for the study because a single source was not available. US News and World Report graded a total of 477 public universities of which the top 250 were studied (USnews.com, 2017). StateUniversity.com (2016) ranked a total of 500 private institutions and 500 community colleges of which the top 250 in each category were surveyed. The criteria used for ranking are different for each source. For example, in the State.University.com (2016) rankings, peer evaluations and peer surveys are replaced with government surveys and self-reports. Consistent factors that affect an institution's rank consist of measures such as student-faculty ratio, total compensation of faculty, retention rate of students, and ACT and SAT scores.

The US News and World Report 2016 ranking of top U.S. public schools was published on February 23, 2016. The private and community college rankings from StateUniversity.com were provided for the year 2015. Data was collected from the course catalogues and websites of each of the 750 institutions between Friday, May 19, 2017 and Friday June 16, 2017. Data collected was at the highest degree and level of curriculum offered, including doctoral, masters and undergraduate levels. For example, if a $\mathrm{PhD}$ 
in entrepreneurship was offered, it was assumed that masters and bachelor's degrees were also offered. The assumption was found to hold when cross-checked against a sub-sample of $25 \%$ of the institutions in the study. A detailed list of colleges used in the sample and details for each type (public, private and community) and level ( $\mathrm{PhD}, \mathrm{MBA}$, undergraduate, club) are available upon request.

\section{Findings}

Entrepreneurship education has a ubiquitous presence on American campuses. The research indicates that $100 \%$ of the 750 institutions surveyed offer some form of entrepreneurship programming, ranging from a PhD program to an entrepreneurship club (See Figure 1). Undergraduate entrepreneurship courses and clubs represent the highest frequency at $78 \%$ and $23 \%$ respectively, and $100 \%$ collectively. Masters level courses are offered at $19 \%$ of institutions surveyed and approximately $4 \%$ of institutions surveyed were found to offer doctoral level majors or minors (Figure 1). Thus, entrepreneurship opportunities were found to exist in every institution within the sample of the top-ranked 750 institutions of higher learning.

\section{FIGURE 1}

\section{UBIQUITOUS ENTREPRENEURSHIP CURRICULUM OFFERINGS I HIGHER EDUCATION}

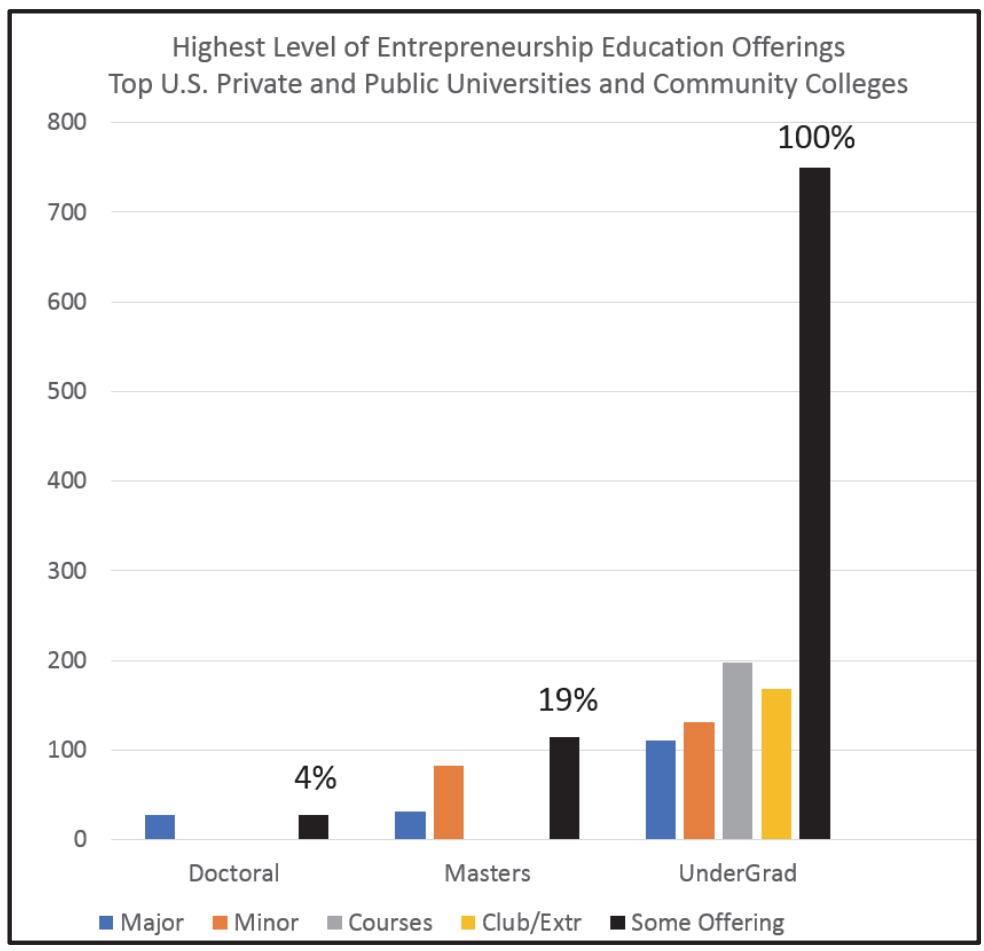

\section{Declining Levels of Entrepreneurship Activity}

Four sources provide credible, longitudinal data regarding trends in entrepreneurship activity in the United States. First, the Bureau of Labor Statistics has published the Business Employment Dynamics (BED) since 1994 (Bureau of Labor Statistics, 2017). The BED tracks new business establishments less than one year old and the associated employment - new jobs created. Other important statistics provided by the BED include the relationship of business births to deaths and the percent distribution of employment by size of firm (Bureaus of Labor Statistics, 2017). According to the BED reports, the U.S. rate of new business creation peaked before the recession, fell $30 \%$ during the recession and has yet to rebound (Harrison, 2015; BLS.gov, 2017). Jobs created from the new businesses is down from a peak of nearly 5 million jobs a year between 1997 and 2000, to less than 3 million jobs a year in 2015 (BLS.gov, 2017) - the last year that reliable figures are available (Greenspan \& Wooldridge, 2018). In addition, the 
BED data shows the percent of smaller firms, as defined by number of employees (1-249), has been decreasing since 1995 as a percent of private sector employment.

A second source of data used to assess new business activity, comes from the U.S. Census Bureau and surfaces a much longer trend of decline in new business activity. The data which is included in Kauffman Foundation and Brooking Institute publications, reports the share of new companies as a percent of all U.S. entities (Buchanan, 2017; Hathaway \& Litan, 2014). This drop in the share of new companies is reflected across every industry sector including tech.

At the same time business startup activity is slowing, the rate of business closures, as tracked by the Brookings Institute since 1970, is increasing (Hathaway \& Litan, 2014). Indicators point to a U.S. economy that has steadily become less entrepreneurial, as evidenced by a thirty year decline, measured by firm entry and job reallocation (Hathaway \& Litan, 2014). Further, the decline is consistent across geography and in both metro and non-metro areas.

The Kauffman Index (1977) provides a fourth source of entrepreneurship activity. The longitudinal index has recently been expanded to go beyond nascent activity and track outcomes, including new company formation and growth rates across city, state and national levels, as well as demographic groups (Kauffman Index of Startup Activity). The Kauffman Index, consistent with measures already discussed, shows peak years for startup activity between 1997 and 2009, followed by the lowest year of startup activity in 2014, and negative indices in years 2011 - 2015. The most recent year (2016) shows some promise of rebound (Kauffman, 2018). Further, the report shows the lowest density rates in startup activity from 2012 thru 2015, continuing in 2016. Startup density is defined as the number of startup firms per 100,000 resident population. Startup firms are defined as firms less than one-year old, employing at least one person besides the owner. During the same period, the index shows a marked decline in young entrepreneurs - a 10-point decline from $34.3 \%$ to $24.7 \%$ in the $20-34$ age group, and a $4-$ point decline in the age group from 27-33 years (Fairlie, Morelix, Reedy, \& Russell, 2015).

Historically, young businesses accounted for nearly all net new jobs created annually in the U.S.(Hathaway \& Litan, 2014) and a disproportionate share of innovation, and as such, young business was deemed the economic growth engine (Buchanan, 2017). The decline in the rate of new business is considered by some to represent a "national emergency" (Buchanan, 2017, p.1).

\section{The Paradox Unfolds}

Literature has provided evidence of a link between education and entrepreneurial intention, activity and performance (Block et al., 2011; Eesley \& Roberts, 2012; Lofstrom et al., 2014; Marvel et al., 2016; Shane, 2003; Van Der Sluis et al., 2008). With education levels at an all-time high, and with pervasive access to entrepreneurship education, why is entrepreneurial activity at an all-time low?

\section{DISCUSSION OF POTENTIAL EXPLANATIONS - THREE MAJOR FORCES CONVERGE}

Given the importance of entrepreneurship to the economy and the recognized decline in activity, some scholars and foundations supporting the development of entrepreneurship in the United States have begun to search for the underlying causes of the decline. For example, in a study of 200 founders, authors discovered five current challenges faced in building new businesses: access to capital following the financial crisis - from any source (bank or family), finding people with the right skill sets, counterproductive immigration policies, onerous regulation and taxation, and economic uncertainty (Dearie \& Geduldig, 2013). The National Federation of Independent Business, publisher of the Small Business Optimism Index since 1973, blames the decline on health care and tax reform uncertainty, and stalled economic growth (NFIB.com, 2017). The Brooking's Institute notes that firms and individuals appear more risk averse and the federal government has not adopted pro-entrepreneurship policies like more liberal immigration (Hathaway \& Litan, 2014). Greenspan \& Wooldridge (2018) agree and suggest that excessive regulation and entitlement programs are choking off programs that could support new

business investment. Experts at Inc.com suggest we have a generational issue compounded by student debt (Zetlin, 2017). Another study proposes that re-cranking the growth engine of startups will require 
significant policy change designed around the recognition that the first five years of life for a startup is most fragile (Dearie \& Geduldig, 2013).

The study focuses the explanation as a perfect storm of three major forces that converged and surfaced during the past decade - the recession, a power shift toward large corporations and a generational shift. While each force is significant on its own, the three are not mutually exclusive. Collectively, the three forces are likely to explain the slow-down in startup activity. Each force and implications are discussed.

\section{Major Force 1: The Financial Crisis and Recession}

The recession took an already burdensome tax and regulatory environment for small business and startups and made it worse. Regulation places a disproportionate burden on small companies (The Economist, 2016). Some economists have suggested that legislators fail to understand that the cultivation of startup activity and entrepreneurship is unique versus small or large business policy.

The recession choked off access to capital and it has yet to be restored. The single greatest deterrent to staring a new business is raising money (Buchanan, 2017). The traditional financial markets do not favor startups (Greenspan \& Wooldridge, 2018). More recently, seed money and angel investing has dried up and venture capitalists are biased toward larger firms and entrepreneurs with a proven track record. VC firms are now two times more likely to invest in a known entity versus seeds. This leaves little funding options for ideas, pre-seed and seed startups and for novice entrepreneurs (Wilmoth, 2016). According to a Small Business Credit Survey (2015), only half the businesses under \$1million in revenue that sought credit were successful in securing it - from any source, including friends and family. Home equity as a source of capital dried up with the financial crisis (Buchanan, 2017; Lofstrom et al., 2014). After a decline following the recession, personal debt levels have climbed back to an all-time high (Wack, 2018). Student loan and credit card debt, established when interest rates were low, are poised to overwhelm personal finances as interest rates rise. Personal debt levels are relevant to entrepreneurs when seeking business loans and credit (Harbour, 2018).

Improvement in the economy and the recent tax reforms should bode well for small business and startups, but it is unclear how long it may take to see a response. The most recent Kauffman Index (2016) shows some promise of startup rate rebound but not startup density. Yet, the uncertainty of trade tariff impact, employee healthcare costs and looming increases in minimum wage remain an anchor for small business and startups (Casselman, 2017). Making up the startup deficit will require dedicated attention, focused on encouraging skill development and recognizing and supporting the fragility of startups during their first five years (Dearie \& Geduldig, 2013).

\section{Major Force 2: Power Shift to Large Corporations}

Historically, the economy has been characterized by short bursts of competition followed by long periods of concentration (The Economist, 2016). A second explanation for the decline in startup activity is the increasing level of concentration in nearly every U.S. industry classification, reducing competition (Casselman, 2017). More recently, dynamic environments have spawned technology giants -"global superstar companies", capable of attracting cash investment well ahead of profits, to rapidly grow to massive scale, and dominate their primary markets while disrupting adjacent markets and industries (Wladawsky-Berger, 2019). The scale of both the incumbents in mature industries and the tech giants affords significant power and advantage over smaller companies and startups. Big business spends close to $\$ 3$ billion on lobby efforts to create favorable regulation and protection from negative changes in regulation (Drutman, 2018). For example, Google became the top spender in 2017, dedicating over $\$ 18 \mathrm{M}$ to influence regulation on issues, including on line advertising, immigration and anti-trust (Shaban, 2018). In addition, large players are absorbing startups prematurely, to squelch competition, and to further insulate their advantage. They are leveraging the data they collect from millions of customers to feed their scale and sustain advantage.

Finally, large companies leveraging their advantage in human capital acquisition, especially with the younger workforce, with strong training programs, job security and higher compensation including 
student debt repayment incentives. as compared to working startups or self-employment (Buchanan, 2017). Choosing to work for a startup or self-employment is expensive and risky as $50 \%$ fail before their fifth year and compensation is lower and often more speculative (Harrison, 2013).

Large corporations have seized the majority from small business and entrepreneurial startups as the majority employer, the majority job creator and the engine of U.S. GDP. Will it be enough?

\section{Major Force 3: Demographic Shift}

A number of demographic changes are creating a drag on startups, including an overall decline in population growth, and two reinforcing generational factors - the aging of the baby boomers and the new millennial majority. First, since the recession, U.S. workforce participation is shrinking, and the population is flattening meaning fewer people to create startups (Buchanan, 2017; Dotsey, Fujita, \& Rudanko, 2018). Workforce participation rate declines are being driven by a reduction in prime age working men and boomer retirements and the trend is expected to continue into future decades (Dotsey, Fujita, \& Rudanko, 2018). Low workforce participation rates distort other ratios and rates that influence the economy. For example, low unemployment rates can be enhanced by fewer people looking for jobs. Next, an older population, driven by the aging of the baby boom generation and lower fertility rates, is generating fewer new businesses. This correlation has been illustrated in Japan and European countries where the decline in overall population and significant aging of the population has resulted in both a reduction in entrepreneurship and decreasing demand for new products (Buchanan, 2017).

The most common age to start a new business is either very young (during or just out of school) or in your 40s. Two studies support a curvilinear relationship between startup activity and age. A Babson study highlighted a higher number of young graduates starting businesses during or immediately following graduation when risk levels and trade-offs were perceived to be low (Lange, Marram, Jawahar, Yong, \& Bygrave, 2014). As traditional job salaries increased over time the motivation for entrepreneurship wanes. Both the Babson and a Berger study found that later, when alumni respondent job dissatisfaction grew or they had a desire to do something different, entrepreneurial activity picks up (Charney \& Libecap, 2003; Lange et al., 2014). The decline in startup activity can be explained by a generational time gap as Baby Boomers, who were prolific in startups during their 40s and 50s, are aging into their 60s - "past the peak demographic bulge" (Buchanan, 2017, np), and Millennials have yet to pick up the slack.

While Millennials have had more exposure to entrepreneurship, higher levels of education, and now represent the majority of the working population (Kauffman, 2015), members of the Millennials generation are not starting businesses at the same rate as previous generations (Thompson, 2017). Student debt levels, averaging $\$ 37 \mathrm{~K}$ in 2016 and including $71 \%$ of recent graduates, may be partly to blame for the lack of Millennial entrepreneurship productivity (Morelix, Fairlie, Reedy, \& Russell, 2016; Zetlin, 2017). High debt is more likely to be associated with additional risk aversion, while propensity for taking risks is a common attribute of entrepreneurs (Busenitz, 1999; Piperopoulos \& Dimov, 2015). Millennials are remaining single and living at home longer - evidence of risk aversion (Stein, 2017). John Lettieri, cofounder of the Economic Innovation Group suggest, "Millennials are on track to be the least entrepreneurial generation in history" (Thompson, 2016, np.).

The Millennial issue may be more significant than debt and risk aversion, representing broader generational attributes that are inconsistent with those of entrepreneurs as suggested in a recent study (Struckell 2018). For example, Millennials proclivity to job hop and need for work/life balance may not match up to the level of focus and perseverance required for entrepreneurial success.

\section{IMPLICATIONS TO PUBLIC POLICY AND EDUCATION}

New business startups have been coined the backbone of the economy (Carland \& Carland, 2015; Harrison, 2013; Kuratko, 2005). For over a decade, startup activity has been in decline. Explanations discussed include the burden of an excessive tax and regulatory climate (Casselman, 2017; Dearie \& Geduldig, 2013; The Economist, 2016), reduced access to startup capital (Buchanan, 2017; Greenspan \& Wooldridge, 2018; Lofstrom et al., 2014; Wilmoth, 2016), demographic changes (Buchanan, 2017; 
Charney \& Libecap, 2003; Lange et al., 2014; Morelix et al., 2016), and the power shift to super-sized newer technology giants and large incumbents in highly concentrated U.S. industry sectors (Buchanan, 2017; Casselman, 2017; Drutman, 2018; Harrison, 2014; The Economist, 2016). Most recently, there is some evidence of a rebound in startup activity, but not startup density (Kauffman Foundation, 2018). The loss of more than a decade of startup momentum will be impossible to make-up and as such the focus should be on regaining momentum. Finally, As established companies attract a greater percentage of graduates, leading to a workforce majority, those employees become vulnerable to the potential future implications of automation and artificial intelligence. In general, the economy will need entrepreneurs to balance potential workforce declines projected in traditional employment.

\section{Public Policy Implications}

Many of the sources reviewed suggest significant public policy changes as the catalyst to creating positive trajectory (Dearie \& Geduldig, 2013; Greenspan \& Wooldridge, 2018; Kauffman Foundation, 2018). Policy makers need to isolate startups from small business and large corporations and provide dedicated focus.

- Seed money for startups has evaporated. The financial markets and venture capitalists favor low risk investments - seasoned ventures run by proven entrepreneurs. It has appropriately been suggested that policy makers provide significant tax credits (as high as $25 \%$ ) to venture capitalists providing seed and angel funding for startups.

- Given the fragile nature of startups, and their importance as an economic growth engine, startup companies should be considered for significant tax rebates during those initial five years of cultivation.

- Millennials graduate with a high degree of debt making the stable paycheck of corporate jobs more enticing than entrepreneurship. Both the public and private sectors need to create incentives to encourage startup activity and provide the incentives over a five-year period following graduation. Employers are now luring graduates with student debt repayment programs as a part of a sign-on and compensation package. To compete with traditional employment, the government could participate in an equity position of a startup in return for student debt forgiveness over time.

- Several sources suggest startup activity is being hampered by uncertainty around the immigration policy. Innovation that drove the U.S. economy was, for the most part, generated by immigrants and children of immigrants (Buchanan, 2017) and policy has choked the immigration pipeline. Flat population can be buoyed with immigration. Further, the Brookings Institute goes a step further to suggest the U.S. should attract immigrant entrepreneurs through facilitated processing of work visas (Hathaway \& Litan, 2014).

- Large and small companies and the government have each reduced the amount of R\&D spending. Restoring government funded $R \& D$ and increasing $R \& D$ tax rebates will encourage innovation and startup activity across all segments, generating new growth and areas of competition - acknowledging $\mathrm{R} \& \mathrm{D}$ activity for large companies includes outsourcing to smaller companies.

- Startups and small business do not have the resources to create a lobby that can compare with large corporations and they bear a disproportionate burden of tax and regulatory change. Perhaps anti-trust legislation should include a provision that large companies seeking merger and acquisition approval should be required to contribute to a startup generation fund (1\%) designed to encourage competition to offset the removal of competitors from the market. 


\section{Education Implications}

No doubt the declines in startup activity are confounded by high levels of education and ubiquitous access to entrepreneurship education. Explanations for the failure of education to offset the startup decline drag are discussed below along with implications.

\section{Education Has Reached a Point of Diminishing Returns}

It is plausible that expanding education to broader populations has diminishing returns on entrepreneurial activity. Some percentage of graduates end up in jobs that did not require a college education. The extra education, while beneficial beyond career interests, may not yield the same level of result as more and more of the population has access. The benefit of education may not be measurable in startup activity.

\section{Entrepreneurs Are Born not Made}

Few studies linking education and entrepreneurship are longitudinal in nature and objective outcome based. Longitudinal studies conducted on the influence of entrepreneurship education on entrepreneurial activity (not intent), suggest a limited relationship. In a Berger study, after controlling for pre-educational intent, the post-education->entrepreneurship intent relationship was found to be insignificant (Bae, Qian, Miao, \& Fiet, 2014). Likewise, in a Babson College study of undergraduate and MBA alumni, covering a 25-year timeframe (1985-2009), and measuring outcomes as the number of new businesses started and the actual economic contribution, found that the most significant predictor of objective outcomes was proclivity to entrepreneurial activity prior to enrollment (Lange et al., 2014). Berger graduates were found to be three times more likely to start a new business after graduation than non-Berger graduates (Charney \& Libecap, 2003).

Highest potential entrepreneurs may self-select the best institutions. Research supports the consideration that all programs, seek to identify and invest in the highest potential entrepreneurs - those with pre-educational intent and experience. In essence, this follows the trend of venture capital firms to funds experienced and more mature ventures. If entrepreneurial potential can be identified early then it can be cultivated (Rodrigues, Dinis, Paco, 2012).

\section{Delay in Startup Activity Versus Never}

Alumni research at Babson and Berger has surfaced that historically startups occur in two age waves. Wave 1 has been represented by a number of young adults starting businesses during or immediately following graduation when risk levels and trade-offs were perceived to be low. As traditional job salaries increase over time, the motivation for entrepreneurship wanes as adults become distracted by family and career. Wave 2 was found to occur later, when alumni job dissatisfaction grew or they had a desire to do something different, entrepreneurial activity picks up (Charney \& Libecap, 2003; Lange et al., 2014). Founders at this age have ideas, experience, money and motivation to transition from corporate career paths. This corresponds to the curvilinear findings presented previously, that boomers in their 40's fueled the last surge in startup activity, but they are now moving into their 60s and activity is falling off (Buchanan, 2017).

Millennials (now 22-38) have yet to reach peak startup age but they are lagging previously generation startup activity at earlier ages (Thompson, 2016). This suggests that the "U" formation may look more like a "J" for the Millennial generation. Educational investment may payoff but simply be delayed. It might also suggest the need for educators to be ready for what might be an even more significant second wave with some sort of second wave educational support. It has been suggested that this generation may live long (100 years +$)$ and change jobs and careers frequently. Educators need to consider how to support the change in careers and longer life spans that are anticipated for the Millennial generation. Further supporting this consideration, as established companies attract a greater percentage of graduates, leading to a workforce majority, those employees become vulnerable to the potential future implications of automation and artificial intelligence. In general, the economy will need entrepreneurs to balance 
potential workforce declines projected in traditional employment, placing an even greater need to consider Wave 2 educational support.

The research and discussion presented suggests strong headwinds facing startup activity for graduates, right out of college. The security of a steady paycheck is compelling. Educational institutions and specifically entrepreneurship curriculum should increase the focus on corporate entrepreneurship to prepare entrepreneurs to take advantage of their entrepreneurial intentions within corporations in lieu of startups - as a first step. Career centers should help students identify career paths and companies that have entrepreneurial cultures and work. For example, management consulting, investment banking, consumer marketing allow students to use their entrepreneurial skills and mindset in more traditional companies. A second option is to provide a better pipeline for graduates into paying internships and permanent positions in startups as employees versus founders. The activity happening within the entrepreneurship centers at many universities can cultivate these opportunities but this objective does not appear to be an organized focus as yet, nor has it been researched.

Possibly the most significant implication is that the Millennial generation is simply not entrepreneurial. Beyond risk aversion, other Millennial attributes such as the need for positive affirmation, impatience, desire for work/life balance and team work (Howe \& Strauss, 2009; Twenge, 2013) may represent a more permanent rift that education cannot reverse. If so, higher education may need to consider reallocation of attention to support skills that match to traditional career paths and leave entrepreneurship education as a niche.

\section{FUTURE RESEARCH AND CONCLUSION}

\section{Future Research}

Future research should follow the longitudinal studies conducted by Babson and Berger to track the education entrepreneurship link through the next generation to better understand the underlying drivers of the paradox between education and entrepreneurship and the generational issues that have surfaced. Because of the significance of the generational factors, future research should bore down into Millennial entrepreneurship and answer questions concerning the influence of debt and Millennial attributes to entrepreneurial intention and activity and to gain insight that will help to predict Millennial entrepreneurship in Wave 1 and Wave 2 and to more appropriately provide educators with direction. Finally, the study surfaces the need to better understand corporate entrepreneurship in the curriculum. Future research could survey top secondary institutions for corporate entrepreneurship curriculum, best practices and student, employer and alumni impact.

\section{Conclusion}

The paper has surfaced a paradox suggesting the uncoupling of the education $>$ entrepreneurship link. While educational levels in the U.S. are at an all-time high, startup activity and density is at a low point. We have lost two decades of entrepreneurial startup activity that will be difficult to replace. Explanations for the decline and educational disconnect are discussed and implications to policy, education and ultimately the economy are discussed. Recognizing the crucial situation presented in this paper, the Brookings Institute is drawing attention of the need for state and local policy to facilitate entrepreneurship. Further, the Kauffman Foundation has created a new economic innovation group designed to remove impediments faced by entrepreneurs (Morelix et al., 2016). Will it be enough? 


\section{REFERENCES}

Bae, T. J., Qian, S., Miao, C., \& Fiet, J. O. (2014). The Relationship Between Entrepreneurship Education and Entrepreneurial Intentions: A Meta-Analytic Review. Entrepreneurship: Theory and Practice, 38(2), 217-254. https://doi.org/10.1111/etap.12095

Block, J. H., Hoogerheide, L., \& Thurik, R. (2011). Education and entrepreneurial choice: An instrumental variables analysis. International Small Business Journal, 31(1), 23-33. https://doi.org/10.1177/0266242611400470

Buchanan, L. (2017). American Entrepreneurship is Actually Vanishing. Here's Why. Inc.

Bureau of Labor Statistics - Business Employment Dynamics 1994-2015 (2017).

Busenitz, L. W. (1999). Entrepreneurial Risk and Strategic Decision Making: It's a Matter of Perspective. The Journal of Applied Behavioral Science, 35(3), 325-340. https://doi.org/10.1177/0021886399353005

Carland, J. W., \& Carland, J. C. (2015). A model of potential entrepreneurship: Profiles and educational implications. Journal of Small Business Strategy, 8(1), 1-14.

Casselman, B. (2017). A Startup Slump Is a Drag on the Economy. New York Times.

CFEE (2014). The National Survey of Entrepreneurship Education An Overview of 2012-2014 Survey Data. International Journal of Entrepreneurship Education

Charney, A., \& Libecap, G. (2003). The Contribution of Entrepreneurship Education: An Analysis of the Berger Program. International Journal of Entrepreneurship Education.

Dearie, J., \& Geduldig, C. (2013). Where the Jobs Are: Entrepreneurship and the Soul of the American Economy. John Wiley \& Sons.

Dotsey, M., Fujita, S., \& Rudanko, L. (2018). Where is Everybody? The Shrinking Labor Force Participation Rate.

Drutman, L. (2018, April). How Corporate Lobbysist Conquered American Democracy. The Atlantic.

Eesley, C. E., \& Roberts, E. B. (2012). Are you experienced or are you talented?: When does innate talent versus experience explain entrepreneurial performance? Strategic Entrepreneurship Journal, 6, 207-219. https://doi.org/10.1002/sej.1141

Fairlie, R., Morelix, A., Reedy, E., \& Russell, J. (2015). The Kauffman Index Startup Activity National Trends.

Foundation, K. (2015). Infographic: Millennial Entrepreneurs and the State of Entrepreneurship, 20152017.

Greenspan, A., \& Wooldridge, A. (2018, October). How to Fix the Great American Growth Machine. Wall Street Journal.

Harbour, S. (2018). How the Kind of Debt You Have Affects Your Loan Chances. Retrieved October 14, 2018, from https://www.fundera.com/blog/type-of-debt-loan-chances

Harrison, J. (2015). The decline of American entrepreneurship — in five charts. The Washington Post, pp. $2-5$.

Harrison, J. D. (2013). Who actually creates jobs: Startups, small businesses or big corporations? The Washington Post, 3-4.

Harrison, J. D. (2014). More businesses are closing than starting. Can Congress help turn that around? The Washington Post, 1-6.

Hathaway, I., \& Litan, R. E. (2014). Declining Business Dynamism in the United States : A Look at States and Metros. Economic Studies at Brookings, (May), 1-7. https://doi.org/10.1613/jair.301

Hmieleski, K. M., \& Baron, R. A. (2016). Entrepreneurs ' Optimism and New Venture Performance : A Social Cognitive Perspective Author ( s ): Keith M . Hmieleski and Robert A . Baron Published by : Academy of Management Stable URL : http://www.jstor.org/stable/40390299 Accessed : 0704-2016 08: The Academy of Management Journal, 52(3), 473-488.

Howe, N., \& Strauss, W. (2009). Millennials Rising: The Next Great Generation. VIntage.

KauffmanFoundation. (2018). Kauffman Index of Startup Activity 1997-2016.

Kuratko, D. (2005). Emergence-of-Entrepreneurship-Education: Development, Trends and challenges. 
Lange, J., Marram, E., Jawahar, A., Yong, W., \& Bygrave, W. (2014). Does an Entrepreneurial Education Have Lasting Value? Journal of Business and Entrepreneurshipntrepreneurship.

Lofstrom, M., Bates, T., \& Parker, S. C. (2014). Why are some people more likely to become smallbusinesses owners than others: Entrepreneurship entry and industry-specific barriers. Journal of Business Venturing, 29(2), 232-251. https://doi.org/10.1016/j.jbusvent.2013.01.004

Maria, J., Praag, V., \& Stel, V. (2011). The Value of an Educated Population for an Individual's Entrepreneruship Success. Econsotor.

Martin, B. C., McNally, J. J., \& Kay, M. J. (2013). Examining the formation of human capital in entrepreneurship: A meta-analysis of entrepreneurship education outcomes. Journal of Business Venturing, 28(2), 211-224. https://doi.org/10.1016/j.jbusvent.2012.03.002

Marvel, M. R., Davis, J. L., \& Sproul, C. R. (2016). Human Capital and Entrepreneurship Research: A Critical Review and Future Directions. Entrepreneurship: Theory and Practice, 40(3), 599-626. https://doi.org/10.1111/etap.12136

Morelix, A., Fairlie, R., Reedy, E., \& Russell, J. (2016). 2016 Kauffman Index Startup Activity Trends.

Nabi, G., Liñán, F., Fayolle, A., Krueger, N., \& Walmsley, A. (2016). The impact of entrepreneurship education in higher education: A systematic review and research agenda. Academy of Management Learning \& Education, 16(2), amle.2015.0026. https://doi.org/10.5465/amle.2015.0026

NCES. (2018). Educational Attainment. Retrieved October 6, 2018, from file://C:/Users/Beth/Desktop/High School Graduation Rates.html

Nicolaou, N., \& Shane, S. (2009). Can genetic factors influence the likelihood of engaging in entrepreneurial activity? Journal of Business Venturing, 24(1), 1-22. https://doi.org/10.1016/j.jbusvent.2007.11.003

Piperopoulos, P., \& Dimov, D. (2015). Burst Bubbles or Build Steam? Entrepreneurship Education, Entrepreneurial Self-Efficacy, and Entrepreneurial Intentions. Journal of Small Business Management, 53(4), 970-985. https://doi.org/10.1111/jsbm.12116

Rampell, C. (2013). Data Reveal a Rise in College Degrees Among Americans. New York Times.

Ryan, C. L., \& Bauman, K. (2016). Educational attainment in the United States: 2015 population characteristics. United States Census Bureau, 2010, 20-578. https://doi.org/P20-578

Shaban, H. (2018). Google Outspent Every Other Company on Federal Lobbying in 2017. The Washington Postashington Post.

Shane, S. (2003). A General Theory of Entrepreneurship: The individual-opportunity nexus. Edward Elgar Publishing.

Stein, J. (2017). Millennials: The Me Me Me Generation. Time Magazine, 7-10.

Struckell, E. (2018). Millennials: A Generation of Un-Entrepreneurs. USASBE Conference. St. Petersburg, FL, 2019.

The Economist. (2016, March). Too Much of a Good Thing. Economist.Com.

The White House. (2018). Empowering American Small Businesses. Retrieved October 6, 2018, from https://www.whitehouse.gov/briefings-statements/empowering-american-small-businesses/

Thompson, D. (2017). The Myth of the Milllennial Entrepreneur. The Atlantic.

Thurik, R. (2008). Entrepreneurship, economic growth and policy in emerging economies. Tinbergen Institute.

Twenge, J. (2013). The Evidence for Generation We and Against Generation Me. Emerging Adulthood, 1(1), 5-10. https://doi.org/10.1177/2167696812466842

Unger, J., Rauch, A., Frese, M., \& Rosenbusch, N. (2011). Human capital and entrepreneurial success: A meta-analytical review. Journal of Business Venturing, 26(3), 341-358. https://doi.org/10.1016/j.jbusvent.2009.09.004

Van Der Sluis, J., Van Praag, M., \& Vijverberg, W. (2008). Education and entrepreneurship selection and performance: A review of the empirical literature. Journal of Economic Surveys, 22(5), 795-841. https://doi.org/10.1111/j.1467-6419.2008.00550.x

Wack, K. (2018). Consumer debt is at an all-time high. Should banks be worried. American Banker. 
Wladawsky-Berger, I. (2019). The Rise of Global, Superstar Firms, Sectors and Cities. The Wall Street Journal. January 18, 2019.

Wilmoth, D. (2016). The Missing Millennial Entrepreneurs. Small Business Exchange, 1-12.

Wilson, R. (2017). Census: More Americans have college degrees than ever before. Retrieved from http://thehill.com/homenews/state-watch/326995-census-more-americans-have-college-degreesthan-ever-before

Zetlin, M. (2017). 63 percent of Millennials Have More Than \$10,000 in Student Debt. They’ll Be Paying for Decades. Inc.Com. 